\title{
Movement, depth and temperature preferences of an important bycatch species, Arctic skate Amblyraja hyperborea, in Cumberland Sound, Canadian Arctic
}

\author{
Iva Peklova ${ }^{1}$, Nigel E. Hussey ${ }^{1}$, Kevin J. Hedges ${ }^{2}$, Margaret A. Treble ${ }^{2}$, \\ Aaron T. Fisk ${ }^{1, *}$ \\ ${ }^{1}$ Great Lakes Institute for Environmental Research, University of Windsor, 401 Sunset Avenue, Windsor N9B 3P4, Ontario, Canada \\ ${ }^{2}$ Freshwater Institute, Fisheries and Oceans Canada, 501 University Crescent, Winnipeg R3T 2N6, Manitoba, Canada
}

\begin{abstract}
Climate change and increasing exploitation of resources are threats to Arctic marine species. Knowledge of vertical and horizontal movements of species is critical to understand their spatial ecology to inform effective ecosystem-based management. Recently, Arctic skate Amblyraja hyperborea, a largely unstudied, cold water, deep-dwelling species has become a common bycatch species in groundfish fisheries throughout the Arctic. To investigate Arctic skate movement, depth and temperature preferences, 9 adults were tagged with pop-off archival transmitting tags in Cumberland Sound, Canadian Arctic, in August 2010 and August 2011 for 40 to 100 d. Of the 9 individuals tagged, 5 transmitted reliable data to satellites. Arctic skate occupied waters between 1.2 and $2.9^{\circ} \mathrm{C}\left(2.5 \pm 0.1^{\circ} \mathrm{C}_{i}\right.$ mean $\left.\pm \mathrm{SD}\right)$ and 317 and $1355 \mathrm{~m}(944 \pm 154 \mathrm{~m})$. Tags popped off within a $37 \mathrm{~km}$ straight-line distance from the tagging location, indicating limited horizontal dispersal during the pre-ice formation period of late summer and early winter. Although mixedeffect models indicated that occupied depth varied with the diel cycle, the relationship was weak and depth variation was small, suggesting diel vertical migration does not appear to be a common strategy. Activity levels, estimated from detailed time series depth profiles, indicated multiple behaviours from resting to large depth changes (>150 m per $0.5 \mathrm{~h})$. Given the levels of bycatch of this species in developing Arctic fisheries, overlap in habitat with the commercially valuable Greenland halibut Reinhardtius hippoglossoides and historical declines of skate populations, it is recommended that the IUCN Red List designation of 'Least Concern' for the Arctic skate be re-evaluated.
\end{abstract}

KEY WORDS: Arctic $\cdot$ Bycatch $\cdot$ Fisheries $\cdot$ Movement $\cdot$ Archival tags $\cdot$ Rajidae

Resale or republication not permitted without written consent of the publisher

\section{INTRODUCTION}

The polar regions remain some of the most pristine biomes on the planet, the harsh environment historically limiting large-scale human settlement and disturbance. With evident changing climatic conditions, fisheries development is underway and is predicted to expand rapidly as sea ice cover continues to retreat (Schrank 2007). Regional fisheries development is of concern given large data deficiencies for many
Arctic fish species, but also provides a unique opportunity to instigate pro-active fisheries management prior to fisheries expansion and over-exploitation. For such precautionary approaches to be adopted, data on the ecology of little known Arctic marine species are pivotal. These data include information from reproductive effort and size at maturity to information on spatial movements (vertical and horizontal) in order to resolve habitat use, multi-species overlap distributions and the scale of species-fisheries inter- 
actions. Spatial data are also important for elucidating how environmental parameters affect species dispersal, abundance and movement (Schick et al. 2008), especially given changing sea ice conditions.

Pop-off archival transmitting (PAT) tags have been widely used to quantify behavioural movement patterns in relation to environmental conditions in a wide range of marine species that are typically difficult to observe (e.g. Sims et al. 2003, Hunter et al. 2004a, Block et al. 2005, Wearmouth \& Sims 2009). Specifically, PAT tags collect light level data that provide geolocation estimates; high-resolution timeseries depth data to describe vertical movements, water column use and behavioural patterns; and environmental data such as depth-temperature profiles to quantify the range of preferred environmental conditions (e.g. Seitz et al. 2003, Sims et al. 2003, Loher 2008). Despite their common application in tropical and temperate climates, the use of PAT tags to study fish in polar ecosystems has been limited (Fisk et al. 2012, Peklova et al. 2012).

Arctic skate Amblyraja hyperborea are mid-sized (total lengths $<95 \mathrm{~cm}$ ) Rajidae that have a circumpolar distribution around both poles. Currently, very little data on the life history of Arctic skates, for example fecundity, length at maturity and growth rate, exists, rendering them largely data deficient (Sulak et al. 2009). Considered a species of 'Least Concern' in the IUCN Red List, a designation based on limited spatial overlap with current fishing activities and the species' distribution at depths beyond most fishing gears (Kulka et al. 2007), Arctic skate is in fact a common bycatch species in Inuit and commercial Arctic fisheries (DFO 2008, Dolgov et al. $2005 \mathrm{a}$, Young 2010). The distribution of this species is restricted to deep (lower continental slope deeper than $650 \mathrm{~m}$ ) and cold waters, with temperatures exclusively $<4^{\circ} \mathrm{C}$ (Bigelow \& Schroeder 1953, Dolgov et al. 2005b, Kulka et al. 2007). Its diet consists of a variety of benthic prey types, but also of pelagic prey, including herring Clupea harengus, blue whiting Micromesistius poutassou, zoarcids and pelagic crustaceans (Last \& Stevens 1994, Bjelland et al. 2000). The flattened body form allows skates to camouflage themselves on the sea bottom, but was traditionally thought to be a trade off for decreased locomotor ability (Schaefer \& Summers 2005), with Rajidae considered to have relatively low activity levels and to exhibit long periods of resting. More recent electronic tagging data has questioned this paradigm, finding some skate species to be more active than originally thought (Wearmouth \& Sims 2009), with some batoids undertaking large-scale movements
(Hunter et al. 2005a,b, Frisk 2010). Nevertheless, being morphologically adapted to a benthic lifestyle, skates typically overlap habitats with numerous demersal fish commonly targeted by commercial fisheries, such as cod Gadus morhua, haddock Melanogrammus aeglefinus, Greenland halibut Reinhardtius hippoglossoides and shrimp Pandalus spp. Recently, Arctic skate have been reported as a principal source of bycatch, along with Greenland sharks Somniosus microcephalus, in the developing Greenland halibut summer fisheries in the Canadian Arctic (K. Hedges pers. obs.).

Cumberland Sound is a large $(250 \mathrm{~km}$ long, $80 \mathrm{~km}$ wide) inlet of Baffin Island; it stretches from the southeastern side of Baffin Island to the Labrador Sea. This system has a bathymetrically diverse bottom of shallow margins and central deep areas, reaching depths of up to $\sim 1500 \mathrm{~m}$ (DFO 2008, Dennard et al. 2009), and represents suitable habitat for a diversity of deep-water species (e.g. Arctic skate, Greenland halibut and Greenland shark) and marine mammals (e.g. beluga Delphinapterus leucas, bowhead whale Balaena mysticetus, ring Pusa hispida and harp seals Pagophilus groenlandicus). Most of Cumberland Sound is covered by land fast ice during the winter season ( December to May/June), and is usually free of land fast ice for the rest of the year. These 2 ice regimes dictate 2 fishing seasons (summer and winter) for commercially targeted Greenland halibut, which are an important economic resource for the local Inuit community of Pangnirtung. Both the summer and winter fishery use bottom long lines deployed from vessels in deep waters (roughly delineated by the $1000 \mathrm{~m}$ contour line) (summer) or through ice in shallower waters (winter) (Fig. 1), respectively, yielding Arctic skate as a major source of bycatch (DFO 2008, Young 2010).

To quantify depth and temperature preferences of Arctic skate, and to determine fine-scale vertical and coarse-scale horizontal movement patterns, PAT tags (MiniPAT, Wildlife Computers) were deployed on adult fish in Cumberland Sound. It was hypothesised that Arctic skate would spend long periods of time resting on the sea bed due to its distinct morphological adaptation and assumed sedentary lifestyle (Wearmouth \& Sims 2009). In addition, it was predicted that the species would be largely independent of diel cycles, because it is assumed to preferentially feed on benthic prey or scavenge on carrion located at the sea bottom rather than feeding in the pelagic water column (Last \& Stevens 1994, Bjelland et al. 2000). Considering that Arctic skate shares similar habitat with Greenland halibut and very little is 


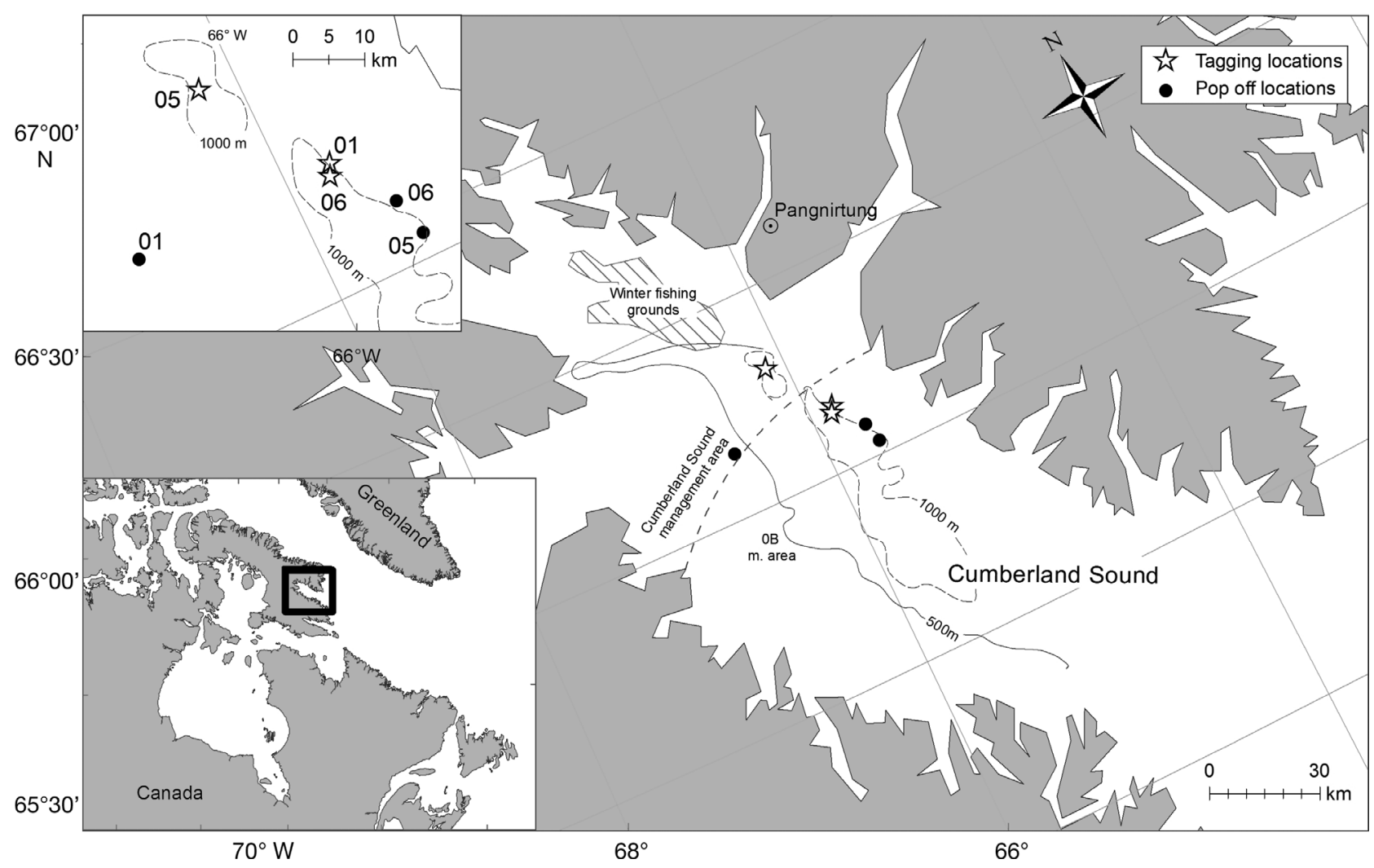

Fig. 1. Amblyraja hyperborea. Tagging and pop-off locations (labelled in inset with fish numbers 01-06) of MiniPAT tags deployed on Arctic skate tagged in August 2010 and 2011 in Cumberland Sound, Baffin Island, Canada. The deep-water area $(>1000 \mathrm{~m})$ corresponds to summer fishery grounds. Contour lines $(500,1000 \mathrm{~m})$ are shown (approximated based on bathymetrical records). Hatched area: winter fishing grounds; dashed line: boundary between Cumberland Sound and Division 0B fisheries management areas

known about this elasmobranch, this research is of particular importance given the future growth of groundfish fisheries in the Arctic and the potential for increasing bycatch of Arctic skate.

\section{MATERIALS AND METHODS}

\section{Study sites}

Tagging of fish was undertaken during 2 consecutives summers (17 August 2010, 9 to 13 August 2011) in Cumberland Sound, Baffin Island, Canada (Fig. 1, Table 1). All skates selected for tagging were caught in the central deep portion of the Sound (from depths of $\sim 800$ to $1100 \mathrm{~m}$; Fig. 1) off a commercial fishing boat (2010) and research vessel (2011) using bottom long lines. In both years, long lines were $\sim 700$ to $2000 \mathrm{~m}$ long, with $\sim 400$ to 1000 gangions of $0.3 \mathrm{~m}$ in length and Mustad's Duratin Tuna Circle (O. Mustad \& Son) hooks size 15 and 16, baited with frozen squid.
Soak times were approximately $12 \mathrm{~h}$. Once removed from the hooks, skates were examined for injuries, and larger individuals (total length [TL] $>62 \mathrm{~cm}$; Table 1) were chosen for tagging. All tagged skates were mature adults based on the presence of calcified claspers in males and the occurrence of large ova in several dissected females of a similar size to tagged individuals, indicating that skates were in mating condition.

\section{Tag attachment and set up}

Assembled MiniPAT tags consisted of a $15 \mathrm{~cm}$ leader wire covered in polyolefin shrink that was crimped to the tag. Following the methods of Wearmouth \& Sims (2009), the tag was attached externally to the animal by feeding the steel leader wire through the mid-section of the wing and securing it in position with 2 disc plates (positioned on the dorsal and ventral sides of the wing). The wire was then 


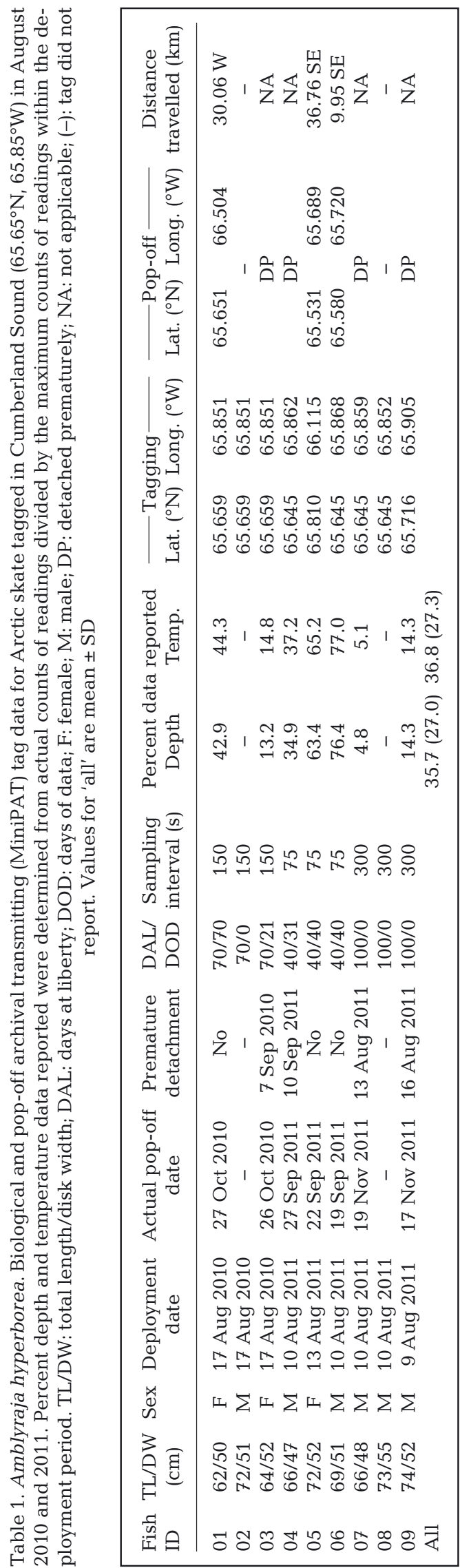

twisted to lock the plate (2010 tagged skates) or crimped behind the plate on the ventral side of the skate's body (2011 tagged skates). Tagging procedures took $<5$ min for each individual.

A total of 9 MiniPAT tags were deployed on male $(\mathrm{n}=6)$ and female $(\mathrm{n}=3)$ Arctic skate (Table 1). MiniPAT tags collect data until a pre-programmed date, when the tag releases, floats to the surface and transmits the accumulated data record to overhead satellites. Tags were programmed to collect time-series data, and to maximise memory capacity, 3 tags were deployed in 2010 for $70 \mathrm{~d}$ (August to October; $150 \mathrm{~s}$ sampling period interval), 3 tags were deployed for $40 \mathrm{~d}$ (August to September; $75 \mathrm{~s}$ interval) and 3 tags were deployed for $100 \mathrm{~d}$ (August to November; $300 \mathrm{~s}$ interval; Table 1) in 2011. Premature release of the tags when low activity is recorded on consecutive days was disabled, considering the presumed benthic lifestyle, with potentially long periods of resting.

\section{Data analysis}

All analyses were performed on time-series depth and temperature data sets that were reported via ARGOS satellites from tags that were successfully retained on fish ( $\mathrm{n}=5$; Table 2 ). To summarise depth and temperature preferences of all fish, data from all deployment periods were pooled into $100 \mathrm{~m}$ bins (range: 300 to $1500 \mathrm{~m}$ ) for depth and $0.5^{\circ} \mathrm{C}$ bins (range: 0.0 to $6.0^{\circ} \mathrm{C}$ ) for temperature (Fig. 2).

To provide a measure of vertical movement activity, the absolute change in depth between 2 consecutive depth measurements was calculated and values were averaged over $10 \mathrm{~min}$ periods for each time-series data set. Actual occupied depths and measures of vertical movement activity were then averaged for each day and for the day/night time period of each day. To test if movement patterns of

Table 2. Amblyraja hyperborea. Mean $( \pm \mathrm{SD}$ in parentheses), maximum and minimum depth and temperature data of Arctic skate monitored using pop-off archival transmitting (MiniPAT) tags in Cumberland Sound in 2010 and 2011

\begin{tabular}{|c|c|c|c|c|c|c|c|}
\hline \multirow{2}{*}{$\begin{array}{l}\text { Fish } \\
\text { ID }\end{array}$} & \multirow{2}{*}{$\begin{array}{l}\text { Months } \\
\text { deployed }\end{array}$} & \multicolumn{3}{|c|}{ Depth $(\mathrm{m})-$} & \multicolumn{3}{|c|}{- Temp. $\left({ }^{\circ} \mathrm{C}\right)$} \\
\hline & & Mean & Max. & Min. & Mean & Max. & Min. \\
\hline 01 & $\mathrm{Al}$ & 2) & 1 & 35 & )) & 2. & 1.2 \\
\hline 03 & Aug & 1061 & 1278 & 836 & 2.42 & 2.6 & 2.1 \\
\hline 04 & Aug & 761 (135) & 1349 & 317 & $2.46(C$ & 2.8 & 2.1 \\
\hline 05 & Aug-Sep & $1130(151)$ & 1329 & 671 & $2.74(0.20)$ & 2.9 & 2.3 \\
\hline 06 & Aug-Sep & 891 (142) & 1115 & 420 & $2.53(0.16)$ & 2.8 & 1.8 \\
\hline All & & 944 (154) & 1355 & 317 & $2.45(0.11)$ & 2.9 & 1.2 \\
\hline
\end{tabular}




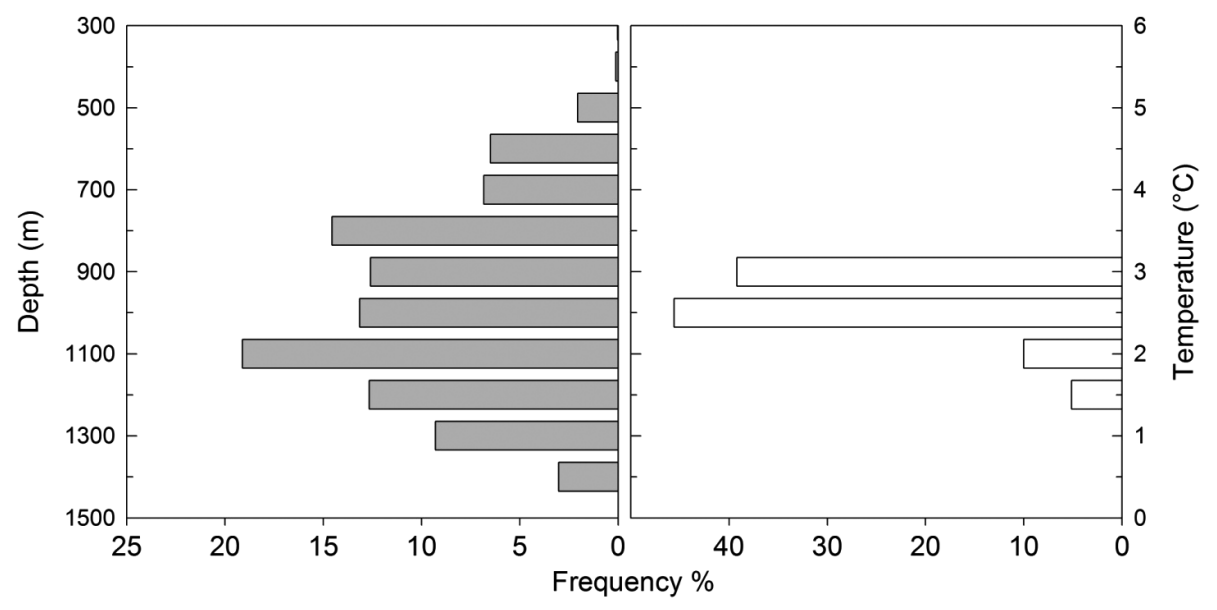

Fig. 2. Amblyraja hyperborea. Depth and temperature preferences of Arctic skate $(\mathrm{n}=5)$, combined over 40 and $70 \mathrm{~d}$ liberty periods (August to October)

skates were related to diel cycles, the relationship between (1) occupied depth and (2) the measure of vertical movement activity for each fish $(\mathrm{n}=5$; Fish 01 and 03 to 06 ) and 4 covariates (day/night, individual fish, week and depth; see Tables $3 \& 4$ ) were analysed by linear mixed-effect models fit using restricted maximum likelihood in the lme4 package in $\mathrm{R}$ ( R Core Team 2012). The day/night covariate (modelled as a fixed effect) was derived from the nautical almanac $\left(66^{\circ} \mathrm{N}\right.$ lat, NavSoft), with each time point (with an associated depth measurement recorded by the tag) assigned to either day or night. Covariates for individual fish, week and depth were considered as random effects in their respective models. The probability plots of residuals from the model relating depth to the day/night covariate showed that the model fit adequately, and the quantile-quantile plot confirmed that data were generally described by normally distributed errors. The absolute change in depth data was log-transformed $\left(X^{\prime}=\log (X+1)\right)$, and zeros (no change in depth) were filtered out to ensure normal distribution of the data. Model parameters were considered significant when $t> \pm 2$.

\section{RESULTS}

\section{Functionality of the tags}

Out of 9 MiniPAT tags deployed on Arctic skate in 2010 and 2011 (total length: $68.7 \pm 4.3 \mathrm{~cm}$ [mean \pm SD]; width: $50.9 \pm 2.4 \mathrm{~cm}$ ), 7 uplinked to ARGOS satellites within days of the programmed pop-off dates $(2 \pm 3 \mathrm{~d}$ after, $\min .=0, \max .=8 \mathrm{~d}$ after;
Table 1), 2 never reported, and 3 tags (Fish 01, 05 and 06) released directly from fish at the preprogrammed date (after 70, 40 and $40 \mathrm{~d}$, respectively). These tags $(\mathrm{n}=7)$ transmitted between 4.8 and $76.4 \%$ (mean: $35.7 \pm 27.0 \%$ ) of the collected depth and 5.1 and $77.0 \%(36.8 \pm 27.3 \%)$ of the temperature time-series data to provide a total of 112 and 116 full days of depth and temperature data, respectively, across all tags (Table 1). None of the tags were physically recovered, nor did they record any light levels when at liberty. Depth profiles showed that 4 tags (Fish 03, 04, 07 and 09) detached prematurely, being afloat for various periods of time (no. of days floating/days deployed: 49/70, 9/40, 97/100 and 93/100 d, respectively) prior to data transmission (Table 1). Overall, 3 tags (Fish 01, 05 and 06) provided biologically relevant data for the entire deployment, and 2 tags (Fish 03 and 04) provided partial records before premature detachment. Data from these 5 tags were included in statistical analyses (Table 1).

\section{Pop-off positions}

The 3 tags that remained on the skates for the full deployment period surfaced in Cumberland Sound at 30,37 and $10 \mathrm{~km}$ straight-line distances away from the respective tagging locations (Table 1) and showed no specific directional movement (Fig. 1). The remaining tags (Fish 03, 04, 07 and 09) reported in Cumberland Sound and the Labrador Sea, but they detached prematurely; thus, the pop-off locations could not be used to assess coarse-scale movements (Table 1). 


\section{Depth and temperature preferences}

Overall, fish with useable data ( $\mathrm{n}=5 ; 40$ to $70 \mathrm{~d}$ liberty periods, August to September/October) ranged between depths of 317 and 1355 m (944 \pm 154 m; Fig. 2, Table 2). Fish did not display any clear temporal pattern at occupied depths (Fig. 3), and spent the majority of the time (86.5 to $96.0 \%$ ) within a depth range of $\sim 400$ to $500 \mathrm{~m}$. The first mixed-effect model examining the relationship between the time-series depth data (actual depth) and day/night (i.e. diel cycle), suggested a significant relationship between the 2 variables $(t>-2$; Table 3 , Fig. 4 A). The overall
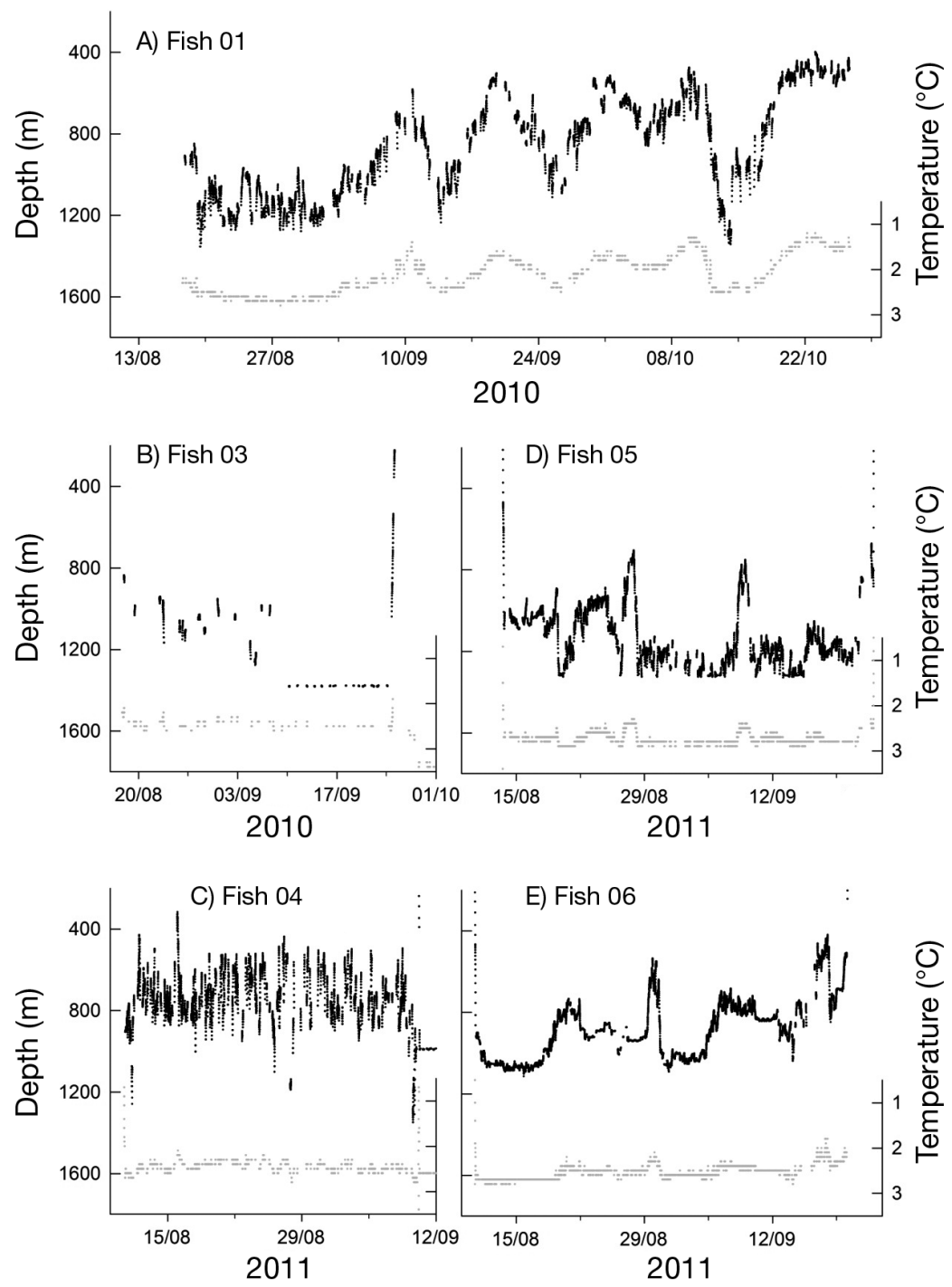

Fig. 3. Amblyraja hyperborea. (A to E) Individual depth (black) and temperature (grey) profiles $(\mathrm{n}=5)$ for 40 and $70 \mathrm{~d}$ deployments of tags attached to Arctic skate (Fish 01, 03, 05, 04 and 06, respectively). Fish 03 and 04 reported constant depths after 7 September 2010 and 10 September 2011, respectively, possibly due to premature detachment of the tag from the fish or due to death of the tagged fish. Dates are $\mathrm{dd} / \mathrm{mm}$ intercept (mean level of depth) was $868 \mathrm{~m}$, with the difference between occupied depth during day and night estimated at $12 \mathrm{~m}$ (Table 3). Fish generally occupied slightly shallower depths during the night period compared to daytime (Fig. 4A), with this pattern observed across months (Fig. 4B). However, this trend was not consistent for all fish (Fig. 4A,B), and the combination of the 2 random-effect covariates (week and individual fish) explained more than twothirds of the variance in the data set. The residual, reflecting differences within the individual data sets (i.e. within a fish), accounted for the remaining variance (Table 3).

Considering that occupied depth may not be a reliable measure of diel vertical migration (DVM), the absolute mean change in depth was used to investigate a potential relationship between activity levels and the diel cycle. The second mixed-effect model examining log-transformed absolute mean change in depth (i.e. vertical movement activity) was not significantly related to the day/night covariate $(t<2$; Table 4$)$. Each of the random-effect covariates (individual fish and depth) accounted for less than a third of the variability (30 and $27 \%$, respectively; Table 4). Consequently, differences among individuals and different depths of occurrence among individuals had minimal influence on the absolute mean change in depth (i.e. vertical movement activity). A large residual (43\%; Table 4) showed that significant variability in the data set was likely explained by differences in vertical movement activity within each (individual's) fish profile.

Fish occurred in a relatively narrow range of temperatures, spending $85 \%$ of their time at temperatures between 2.0 and $2.9^{\circ} \mathrm{C}\left(2.5 \pm 0.1^{\circ} \mathrm{C}\right)$ and the remaining $15 \%$ in water temperatures between 1.2 and $2.0^{\circ} \mathrm{C}$ (Fig. 2).

\section{Vertical movement activity}

Detailed depth profiles recorded by the 75 and $150 \mathrm{~s}$ sampling period intervals (Fish 01, 04, 05 and 06) showed variability in vertical ranging 
Table 3. Results of the mixed-effect model for depth with crossed random effects. Depth $(n=90214)$ was the dependent variable, individual fish $(n=5)$ and week $(n=6)$ were treated as random covariates and day/night was included as a fixed covariate

\begin{tabular}{|lcccc|}
\hline Random effects & Variance & SD & \\
\hline Individual fish (Intercept) & 25164 & 158.63 & \\
Week (Intercept) & 32838 & 181.21 & \\
Residual & 20595 & 143.51 & \\
& & & \\
Fixed effects & Estimate & SE & $t$-value \\
\hline (Intercept) & 867.9089 & 102.3111 & 8.483 \\
Day/night & -12.0267 & 0.9893 & -12.157 \\
Correlation of fixed effects & -0.003 & & \\
\hline
\end{tabular}

and vertical movement activity levels within and among individual fish (e.g. Figs. 3 \& 5). Periods of minimal vertical ranging, i.e. low activity levels potentially indicating resting, were displayed as horizontal lines in the time-series data (Fig. 5B,C, $\mathrm{E}, \mathrm{F})$. These periods lasted from $\sim 1$ to $48 \mathrm{~h}$, and were commonly observed throughout the time-series depth data of 2 individuals (Fish 05 and 06). High levels of vertical movement activity (over $\sim 100$ to $300 \mathrm{~m}$ every 0.5 to $1 \mathrm{~h}$ ) were also recorded. Aside

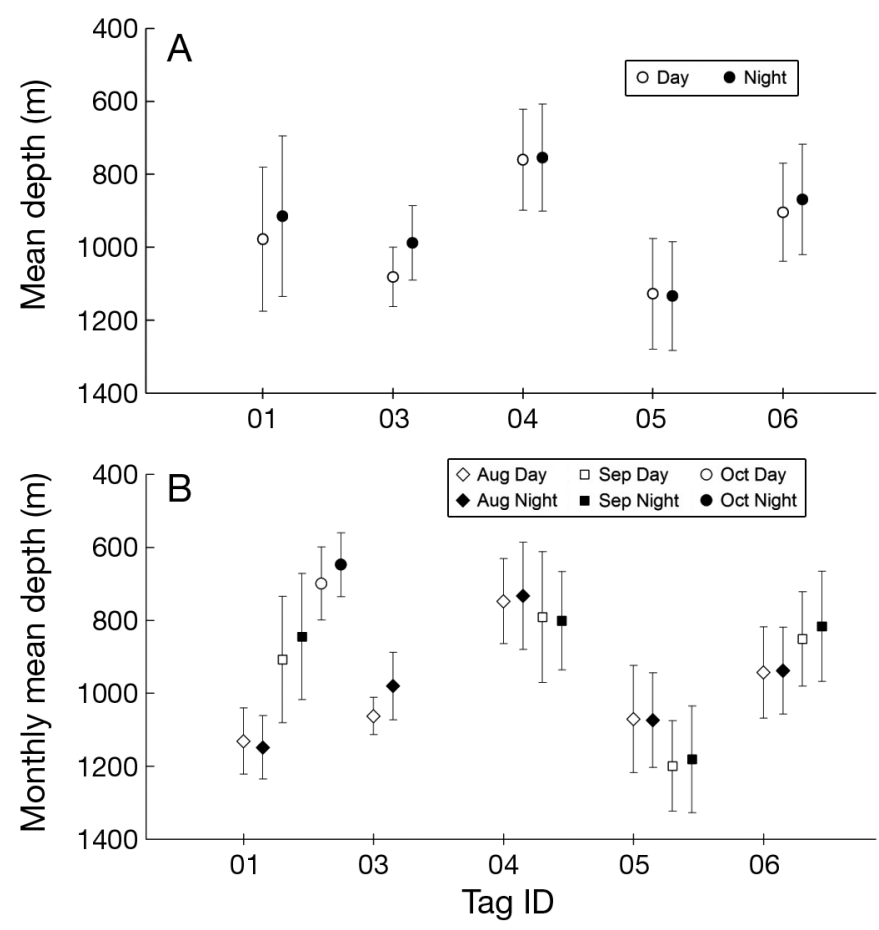

Fig. 4. Amblyraja hyperborea. (A) Mean depths $( \pm \mathrm{SD})$ for individual Arctic skate ( $\mathrm{n}=5$; Fish 01, 03, 04, 05 and 06) during day and night and (B) during day and night in individual months (August to October)
Table 4. Results of the mixed-effect model for activity level with crossed random effect. Absolute mean change in depth ( $\mathrm{n}=59842)$, a measure of vertical movement activity was the dependent variable, individual fish $(\mathrm{n}=5)$ and depth (all depths, at $0.5 \mathrm{~m}$ resolution, ever occupied by any of the fish; $\mathrm{n}=1616$ ) were treated as random covariates and day/night was included as a fixed covariate

\begin{tabular}{|lcccc|}
\hline Random effects & Variance & $\mathrm{SD}$ & \\
\hline Individual fish (Intercept) & 0.034742 & 0.18639 & \\
$\begin{array}{l}\text { Depth (Intercept) } \\
\text { Residual }\end{array}$ & 0.028025 & 0.16741 & \\
& 0.068305 & 0.26250 & \\
Fixed effects & Estimate & $\mathrm{SE}$ & $t$-value \\
\hline (Intercept) & 1.079579 & 0.083507 & 12.928 \\
$\begin{array}{l}\text { Day/Night } \\
\text { Correlation of fixed effects }\end{array}$ & -0.001677 & 0.002358 & -0.711 \\
\hline
\end{tabular}

from 1 individual (Fish 04) that displayed principally vertical movement activity throughout the entire deployment period (Fig. 3C), the remainder of the fish appeared to switch between lower and higher activity levels, with no apparent trends in the frequency or amplitude of these vertical movements (e.g. Fig. 3A,D,E).

The absolute mean change in depth data for tagged Arctic skate indicated 2 vertical movement behaviours. Individuals either undertook large continuous vertical movements, with this behaviour seen over a wide range of starting depths (vertical displacement $>100 \mathrm{~m} \mathrm{~h}^{-1}$ ), or they performed short and repeated upward and downward movements.

\section{DISCUSSION}

Although Arctic skate did not range into shallower waters (the minimum depth was $317 \mathrm{~m}$ ), they occupied a wide range of depths (317 to $1355 \mathrm{~m}$ ) and occurred close to the maximum depth $(\sim 1500 \mathrm{~m})$ of Cumberland Sound. Tagged Arctic skate were not confined to the deep-water areas in the central part of the Sound during the ice-free period of the year, but also ranged into shallower coastal margins. This contrasts the behaviour of Greenland halibut within this system, which typically occupied deep waters ( $>900 \mathrm{~m}$ ) during the ice-free period (Peklova et al. 2012). Nonetheless, tagged Arctic skate spent significant amounts of time in depths targeted by the fishery for Greenland halibut during this season, confirming the issue of Arctic skates as a bycatch species (Dolgov et al. 2005a, Young 2010). Arctic skate experienced a narrow range of temperatures, which is 


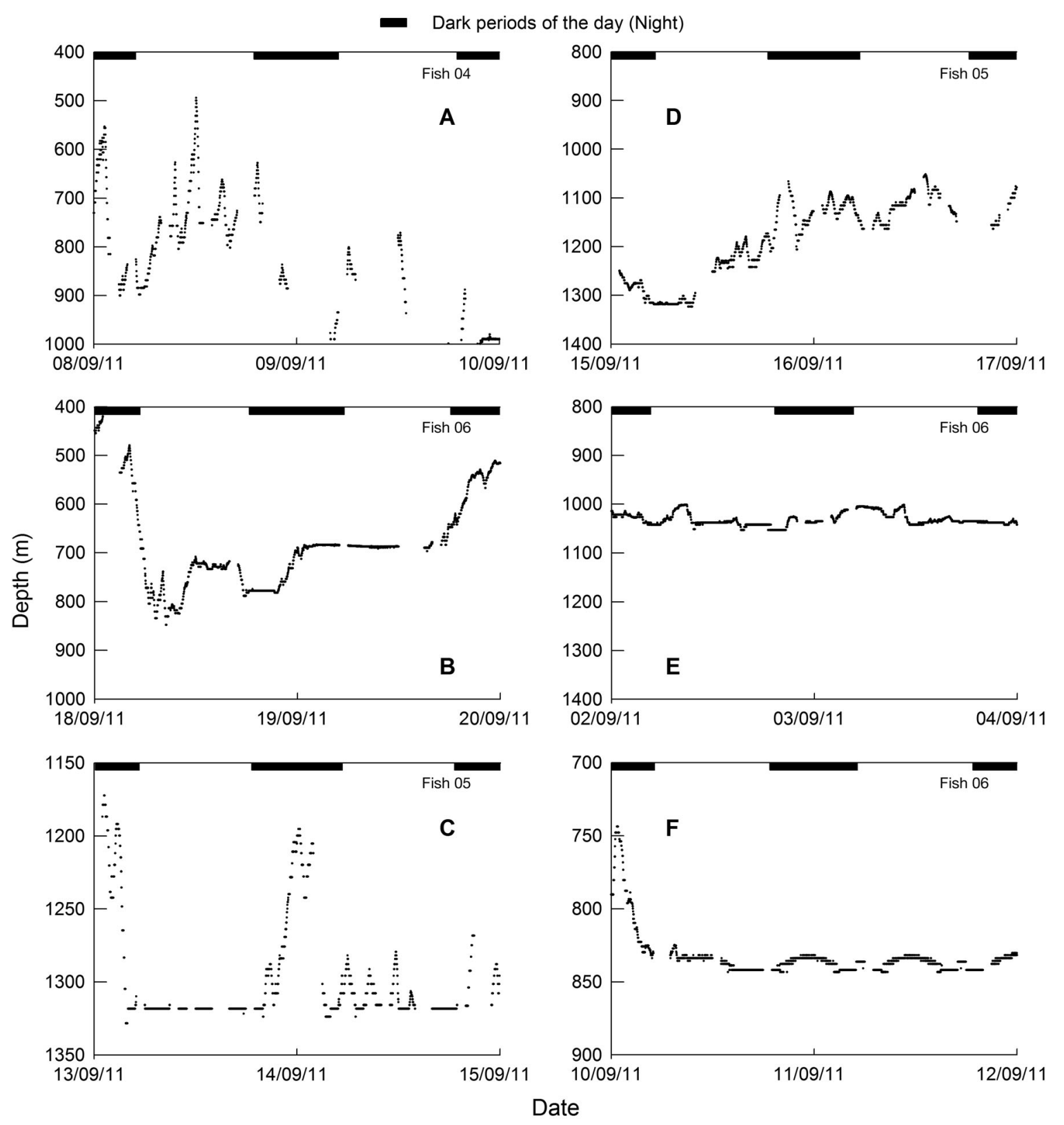

Fig. 5. Amblyraja hyperborea. Detailed (75 s sampling period interval) individual depth profiles for Arctic skate (n = 3) showing different types of behaviour during the light and dark (black horizontal bars) periods of the day: (A) high activity, wide vertical ranging (Fish 04); (B) high activity interspersed with low and moderate activity (Fish 06); (C) low activity during light period of the day, high activity during the dark period of the day (Fish 05); (D) high activity, narrow vertical ranging (Fish 05); (E) moderate activity (Fish 06); and (F) seabed resting (Fish 06). Gaps in the depth profiles denote incomplete transmission of archival records via satellites. Dates are given as dd/mm/yy

likely related to the stable temperature regimes below $800 \mathrm{~m}$ and overall low temporal variability in water temperatures in Cumberland Sound (J. Bedard unpubl. data).

Similar to the common skate Dipturus batis, Arctic skate did not show much evidence of a sedentary lifestyle (Wearmouth \& Sims 2009), but instead displayed high activity levels interspersed with periods of resting. High activity levels of Arctic skate were associated with 2 distinct behaviours - large continuous vertical movements or repeated small upward and downward movements. These 2 behaviours may potentially be a result of differences in movement that reflect opportunistic foraging and/or could be a result of movement over the heterogeneous bottom topography of Cumberland Sound. 
Model results indicated that depth occupied by Arctic skate varied significantly between day and night, with skate occupying slightly shallower waters during the night period. However, differences in depth between these 2 periods were minimal $(\sim 12 \mathrm{~m})$, and large variance in individual depth profiles suggest occupied depths are not strongly related to diel cycles. Activity levels were not tied to diel cycles; thus, it would appear that movement patterns of Arctic skate were not driven by DVM.

\section{Tag performance}

Despite the relatively high recovery rate of MiniPAT tags in this study ( 7 out of 9), 4 of the 7 tags that uplinked to satellites provided only partial records or few data. These tags reported constant depths ( $>3 \mathrm{~d}$, e.g. Fish 03; Fig. 3B) until the tag link corroded and the tag popped off. This suggested that the animals had either died during the deployment period or the tag had detached from the animal through the attachment mechanism tearing through the thin musculature of the wing. The tags likely remained at depth because of the additional weight of the anchoring mechanism attached to the tag prior to the link corroding (H. Baer pers. comm.). Given the high rate of prematurely detached tags, a different method for attaching satellite tags to this mid-sized batoid species should be considered (e.g. see Le Port et al. 2008). Variability in the rate of transmission (4.8 to $77.0 \%$ ) likely reflected weather conditions; however, tags that detached prematurely were generally the least successful in transmitting archival records (Table 1).

\section{Depth preference}

The observed depth range occupied by both male and female Arctic skate (300 to $1350 \mathrm{~m}$ ) was consistent with that previously reported (140 to $2500 \mathrm{~m}$; Artuykhin \& Sheyko 2000, Dolgov et al. 2005b). Arctic skate spent most of their time below $500 \mathrm{~m} \mathrm{(97 \% )}$ in Cumberland Sound, as in the Barents Sea, where they were most abundant below $650 \mathrm{~m}$ (Dolgov et al. 2005a, Kulka et al. 2007). Individual Arctic skates moved to shallower waters at times, but movement between deeper and shallower waters was sporadic, contrasting that of Greenland halibut that remained in deeper water (>900 m) during the ice-free period (Peklova et al. 2012).

\section{Temperature preference}

Arctic skate experienced a narrow range of temperatures, from 1.2 to $2.9^{\circ} \mathrm{C}$ and spent $95 \%$ of their time within 2.0 to $2.9^{\circ} \mathrm{C}$ (over the 2 tagging seasons). This range was well within the estimated margins of their temperature tolerance (Kulka et al. 2007) and was within a suitable temperature range for sexual maturation and potential spawning based on the successful incubation of eggs at temperatures down to $0^{\circ} \mathrm{C}$ (Bigelow \& Schroeder 1953). Given that the water temperature at depths below $120 \mathrm{~m}$ in Cumberland Sound does not exceed the preferred thermal limits of Arctic skate over the course of a year (J. Bedard unpubl. data) and due to the narrow temperature range experienced by the skates, temperature was not expected either to limit or drive the movement patterns observed in this region over the deployment period.

\section{Activity levels and vertical movement}

Activity levels of Arctic skate based on depth profiles and changes in depth over short sampling intervals (75 to $150 \mathrm{~s}$ ) ranged in a continuum from low to relatively high. Overall, some of the fish appeared to be highly active (depth changes of 100 to $300 \mathrm{~m}$ per $0.5 \mathrm{~h}$ ), shown by constantly changing movements in depth. This contrasts the general notion that flatfish are less active and spend long periods of time resting on the sea bottom (Hunter et al. 2004a) and is in agreement with more recent findings that suggest higher activity levels (Wearmouth \& Sims 2009).

Activity level data indicated 3 distinct behavioural types, which varied within and among individual fish. The first behavioural type was indicated by long (>30 min) periods where the fish remained at the same depth. This behaviour likely indicated resting at the sea bottom and has previously been described for other undulatory batoids monitored by electronic tags, e.g. common skate and thornback ray Raja clavata (Hunter et al. 2005a, Wearmouth \& Sims 2009). Alternatively, the fish may have been swimming over a flat bottom area; however, this is unlikely considering the heterogenous topography of Cumberland Sound. Resting behaviour was common throughout the depth profiles of 2 fish, a female and a male (Figs. 3D,E \& 5B,C) and was typically interspersed with periods of vertical activity. A second behavioural type, exhibited by 1 male (Figs. 3C \& 5A), involved higher activity levels, with vertical displacements of 100 to $300 \mathrm{~m} \mathrm{~h}^{-1}$ similar to the oscillatory behaviour of pelagic fish species such as yel- 
lowfin tuna Thunnus albacores, shortfin mako sharks Isurus oxyrinchus and basking sharks Ceterohinus maximus (Sims et al. 2003, Shepard et al. 2006, Schaefer et al. 2007), but at a much slower rate. The third distinct behavioural type was multiple movements (upward and downward) within a narrow range of depth, a pattern previously documented in the common skate (Wearmouth \& Sims 2009). The latter 2 types of behaviour may reflect distinct modes of foraging either on the bottom following the topography or potentially in the water column as proposed for the common skate (Wearmouth \& Sims 2009).

DVM is a known factor driving the movement of a number of fish and elasmobranch species that occupy pelagic habitats (Carey \& Scharold 1990, Reebs 2002, Shepard et al. 2006), as well as benthic species such as lesser spotted dogfish Scyliorhinus canicula, bat rays Myliobatis californica and the common skate (Matern et al. 2000, Sims et al. 2006, Wearmouth \& Sims 2009). The results of the mixed-effect model found a relationship between depth and the diel cycle, with skates generally occupying shallower waters during the night time (Fig. 4). However, this trend was not consistent among all individuals, and the difference in depth was minimal (<12 m), suggesting this may not be biologically relevant. In addition, activity levels did not vary with diel cycles. Consequently, DVM may not be a common behaviour of Arctic skate, but might be adopted by some individuals (Fig. 5C). Such inter-individual variability in activity levels has been reported in the short-tailed stingray Dasyatis brevicaudata and the common skate (Le Port et al. 2008, Wearmouth \& Sims 2009).

Individual Arctic skate showed variability in preferred depth range and relative amount of time spent resting versus actively moving. Activity levels were not significantly different between males and females in this study, but sample size was small. Due to the fact that all tagged individuals were of a similar size (Table 1), it is unlikely that ontogenetic changes in swimming speed, behaviour, or preferred prey explained the variability in activity among individuals, as previously observed for thorny Raja radiata and common skates (Skjæraasen \& Bergstad 2000, Wearmouth \& Sims 2009). Alternatively, the short tag deployment periods in this study might not provide a full representation of the normal movement behaviours of Arctic skates, as behaviour may also vary seasonally as a response to cyclical changes in the abiotic environment such as ice cover. For example, the movement of acoustically monitored freshwater whiprays Himantura dalyensis was driven by the diel cycle during the wet season, whereas movement was dictated by lunar and tidal cycles during the dry season (Campbell et al. 2012).

\section{Horizontal movement}

Arctic skate travelled short horizontal distances $(<30 \mathrm{~km})$ between tagging and pop-off locations; however, the reported straight-line distance was likely an underestimation of the distance travelled during the time at liberty. It was determined that plaice (a bottom-dwelling flatfish) moved approximately 10 times farther than the direct distance estimated between release and recapture positions (Metcalfe \& Arnold 1997, Hunter et al. 2004b). Based on pop-off locations and the long time periods Arctic skate spent in shallower waters, Arctic skates were not confined to the deep-water tagging region, but dispersed into shallower areas. In contrast to this observation, Greenland halibut (another bottomdwelling fish) spent most of their time at liberty below $900 \mathrm{~m}$ during the ice-free period in the same system (Peklova et al. 2012). Considering that Arctic skate were monitored for a relatively short deployment period, further study should clarify long-term movement patterns and potential seasonal migrations.

\section{Conservation considerations}

The depth range occupied by Arctic skate largely overlapped with that of Greenland halibut in Cumberland Sound. Overlapping vertical habitats are common for skates and flatfish and usually result in significant skate bycatch in commercial groundfish fisheries (Dolgov et al. 2005a, Stevenson \& Lewis 2008, Ormseth et al. 2009), which can lead to population decline to the point of local extirpation (Stevens et al. 2000). Caution is therefore required for the management of Arctic skate in the Arctic region, in light of the developing Cumberland Sound Greenland halibut fisheries and Arctic fisheries overall. This is particularly pertinent for Arctic skate given their unknown life-history traits, with potentially low fecundity, slow growth and maturation rates typical for other skate species (Kulka et al. 2007) and elasmobranch species (Bonfil 1994, Stevens et al. 2000, Dulvy \& Reynolds 2002, Sims 2008), which may be even further accentuated in extremely cold habitats. It may therefore be prudent for the designation of Arctic skate in the IUCN Red List to be reassessed in order to adopt a precautionary approach to fisheries management in the Arctic region. 
Acknowledgements. The authors thank A. MacNeil and J. Olin for help with statistical analyses, and J. Weberschinke for help with data management. The authors also thank S. Kirchhoff, T. Gruninger, P. Tatchell, J. Cheater, M. Marcoux, E. Primeau, K. Ulrich, A. Young and D. Imrie for their help in the field. Funding and resources for this study were provided by the Natural Sciences and Engineering Research Council of Canada and the Canadian Foundation for Innovation (Ocean Tracking Network), Fisheries and Oceans Canada and the Government of Nunavut to A.T.F., N.E.H. and K.J.H., as well as University of Windsor scholarships to I.P. This project was approved by the Hunters and Trappers Association of Pangnirtung and the Animal Care Committee at the University of Windsor.

\section{LITERATURE CITED}

Artuykhin YUB, Sheyko BA (eds) (2000) Catalog of vertebrates of Kamchatka and adjacent waters. Rossiyskaya Akademiya Nauk, Moscow

Bigelow HB, Schroeder WC (1953) Fishes of the western North Atlantic, Part 2. Sawfishes, guitarfishes, skates and rays; Chimaeroids. Yale University, New Haven, CT

Bjelland O, Bergstad OA, Skjæraasen JE, Meland K (2000) Trophic ecology of deep-water fishes associated with the continental slope of the eastern Norwegian Sea. Sarsia 85:101-117

Block BA, Teo SLH, Walli A, Boustany A and others (2005) Electronic tagging and population structure of Atlantic bluefin tuna. Nature 434:1121-1127

Bonfil R (1994) Overview of world elasmobranch fisheries. FAO Fish Tech Pap No 341, FAO, Rome

Campbell HA, Hewitt M, Watts ME, Peverell S, Franklin CE (2012) Short- and long-term movement patterns in the freshwater whipray (Himantura dalyensis) determined by the signal processing of passive acoustic telemetry data. Mar Freshw Res 63:341-350

Carey FG, Scharold JV (1990) Movements of blue sharks (Prionace glauca) in depth and course. Mar Biol 106: 329-342

> Dennard ST, MacNeil MA, Treble MA, Campana S, Fisk AT (2009) Hierarchical analysis of a remote, Arctic, artisanal longline fishery. ICES J Mar Sci 67:41-51

DFO (Department of Fisheries and Oceans) (2008) Cumberland Sound Greenland halibut (turbot) inshore fishery. DFO Can Sci Advis Sec Sci Rep 2008/40, Fisheries and Oceans Canada, Winnipeg

Dolgov AV, Grekov AA, Shestopal IP, Sokolov KM (2005a) By-catch of skates in trawl and long-line fisheries in the Barents Sea. J Northwest Atl Fish Sci 37:357-366

Dolgov AV, Drevetnyak KV, Gusev EV (2005b) The status of skate stocks in the Barents Sea. J Northwest Atl Fish Sci 35:249-260

> Dulvy NK, Reynolds JD (2002) Predicting extinction vulnerability in skates. Conserv Biol 16:440-450

> Fisk AT, Lydersen C, Kovacs KM (2012) Archival pop-off tag tracking of Greenland sharks Somniosus microcephalus in the High Arctic waters of Svalbard, Norway. Mar Ecol Prog Ser 468:255-265

Frisk MG (2010) Life history strategies of batoids. In: Carrier JC, Mucisk JA, Heithaus MR (eds) Sharks and their relatives. II. Biodiversity, adaptive physiology and conservation. CRC Press, Boca Raton, FL, p 283-316
Hunter E, Metcalfe JD, O'Brien CM, Arnold GP, Reynolds JD (2004a) Vertical activity patterns of free-swimming adult plaice in the southern North Sea. Mar Ecol Prog Ser 279:261-273

> Hunter E, Metcalfe JD, Holford BH, Arnold GP (2004b) Geolocation of free-ranging fish on the European continental shelf as determined from environmental variables. II. Reconstruction of plaice ground-tracks. Mar Biol 144: 787-798

> Hunter E, Buckley AA, Stewart C, Metcalfe JD (2005a) Migratory behaviour of the thornback ray, Raja clavata, in the southern North Sea. J Mar Biol Assoc UK 85: 1095-1105

> Hunter E, Buckley AA, Stewart C, Metcalfe JD (2005b) Repeated seasonal migration by a thornback ray in the southern North Sea. J Mar Biol Assoc UK 85:1199-1200

Kulka DW, Barker AS, Pasolini P, Orlov A (2007) IUCN Red List of Threatened Species. http://iucnredlist.org (accessed 9 April 2012)

Last PR, Stevens JD (1994) Sharks and rays of Australia. CSIRO, Melbourne

- Le Port A, Sippel T, Montgomery JC (2008) Observations of mesoscale movements in the short-tailed stingray, Dasyatis brevicaudata from New Zealand using a novel PSAT tag attachment method. J Exp Mar Biol Ecol 359:110-117

Loher T (2008) Homing and summer feeding site fidelity of Pacific halibut (Hippoglossus stenolepis) in the Gulf of Alaska, established using satellite-transmitting archival tags. Fish Res 92:63-69

Matern SA, Cech JJ, Hopkins TE (2000) Diel movements of bat rays, Myliobatis californica, in Tomales Bay, California: evidence for behavioral thermoregulation? Environ Biol Fishes 58:173-182

Metcalfe JD, Arnold GP (1997) Tracking fish with electronic tags. Nature 387:665-666

Ormseth O, Matta B, Hoff J (2009) Bering Sea and Aleutian Islands skates. In: Stock assessment and fishery evaluation report for the groundfish resources of the Bering Sea/Aleutian Islands region. NMFS Alaska Fisheries Science Center, Seattle, WA

Peklova I, Hussey NE, Hedges KJ, Treble MA, Fisk AT (2012) Depth and temperature preferences of the deepwater flatfish, Greenland halibut Reinhardtius hippoglossoides in an Arctic marine ecosystem. Mar Ecol Prog Ser 467:193-205

R Core Team (2012) R: A language and environment for statistical computing. R Foundation for Statistical Computing, Vienna. www.r-project.org

Reebs SG (2002) Plasticity of diel and circadian activity rhythms in fishes. Rev Fish Biol Fish 12:349-371

Schaefer JT, Summers AP (2005) Batoid wing skeletal structure: novel morphologies, mechanical implications, and phylogenetic patterns. J Morphol 264:298-313

Schaefer KM, Fuller DW, Block BA (2007) Movements, behavior, and habitat utilization of yellowfin tuna (Thunnus albacares) in the northeastern Pacific Ocean, ascertained through archival tag data. Mar Biol 152:503-525

Schick RS, Loarie SR, Colchero F, Best BD and others (2008) Understanding movement data and movement processes: current and emerging directions. Ecol Lett 11: 1338-1350

Schrank W (2007) The ACIA, climate change and fisheries. Mar Policy 31:5-18

Seitz AC, Wilson D, Norcross BL, Nielsen JL (2003) Pop-up archival transmitting (PAT) tags: a method to investigate 
the migration and behavior of Pacific halibut Hippoglossus stenolepis in the Gulf of Alaska. Alsk Fish Res Bull 10:124-136

Shepard ELC, Ahmed MZ, Southall EJ, Witt MJ, Metcalfe JD, Sims DW (2006) Diel and tidal rhythms in diving behaviour of pelagic sharks identified by signal processing of archival tagging data. Mar Ecol Prog Ser 328: 205-213

Sims DW (2008) Sieving a living: a review of the biology, ecology and conservation status of the plankton-feeding basking shark Cetorhinus maximus. Adv Mar Biol 54: $171-220$

Sims DW, Southall EJ, Richardson AJ, Reid PC, Metcalfe JD (2003) Seasonal movements and behaviour of basking sharks from archival tagging: no evidence of winter hibernation. Mar Ecol Prog Ser 248:187-196

Sims DW, Wearmouth VJ, Southall EJ, Hill JM and others (2006) Hunt warm, rest cool: bioenergetic strategy underlying diel vertical migration of a benthic shark. J Anim Ecol 75:176-190

Skjæraasen JE, Bergstad OA (2000) Distribution and feeding ecology of Raja radiata in the northeastern North Sea

Editorial responsibility: Cornelius Hammer, Rostock, Germany and Skagerrak (Norwegian Deep). ICES J Mar Sci 57: 1249-1260

Stevens JD, Bonfil R, Dulvy NK, Walker PA (2000) The effects of fishing on sharks, rays, and chimaeras (chondrichthyans), and the implications for marine ecosystems. ICES J Mar Sci 57:476-494

Stevenson GE, Lewis KA (2008) Observer-reported skate bycatch in the commercial groundfish fisheries of Alaska. Fish Sci 108:208-217

Sulak KJ, MacWhirter PD, Luke KE, Norem AD, Miller JM, Cooper JA, Harris LE (2009) Identification guide to skates (family Rajidae) of the Canadian Atlantic and adjacent regions. Can Tech Rep Fish Aquat Sci 2850: viii, p 1-46

Wearmouth VJ, Sims DW (2009) Movement and behavior patterns of the critically endangered common skate Dipturus batis revealed by electronic tagging. J Exp Mar Biol Ecol 380:77-87

Young A (2010) Development of the Cumberland Sound inshore summer fishery 2009. Government of Nunavut Department of Environment Fisheries and Sealing Division, Iqaluit

Submitted: May 8, 2013; Accepted: October 26, 2013

Proofs received from author(s): January 19, 2014 